\title{
Markers of airway inflammation in pulmonary diseases assessed by induced sputum
}

\author{
S. Dragonieri1, O. Tongoussouva1' A. Zanini², A. Imperatori3 ${ }^{3}$ A. Spanevello2
}

ABSTRACT: Markers of airway inflammation in pulmonary diseases assessed by induced sputum. S. Dragonieri, O. Tongoussouva, A. Zanini, A. Imperatori, A. Spanevello.

During recent years there has been a growing interest in using non-invasive biomarkers to understand and monitor the airway inflammation in subjects with respiratory tract disorders.

To date, the best validated and performing non-invasive biomarkers are measures of inflammation in induced sputum in both cellular and fluid phase, which can provide biological insights into the pathogenesis of respiratory diseases such as asthma and chronic obstructive pulmonary disease.

The purpose of this review is to examine the principal literature on the different markers of inflammation in pulmonary diseases assessed by induced sputum analysis in either cellular or fluid phase.

Monaldi Arch Chest Dis 2009; 71: 3, 119-126.

Keywords: Induced sputum, Airway inflammation, Mediators.

I Department of Pulmonology, Fondazione Salvatore Maugeri, Cassano delle Murge,

2 Department of Pulmonology, Fondazione Salvatore Maugeri, Dept. of Clinical Medicine, Section of Respiratory Diseases, University of Insubria, Tradate,

3 Center for Thoracic Surgery, University of Insubria, Varese, Italy.

Correspondence: Dr. Silvano Dragonieri, Department of Pulmonology, Fondazione Salvatore Maugeri, Via per Mercadante km. 2, 70020 Cassano delle Murge, Italy; e-mail address: silvano.dragonieri@fsm.it

Conflict of interest: None of the authors have a financial relationship with a commercial entity that has an interest in the subject of this article.

\section{Introduction}

Induced sputum analysis has become an important direct, non-invasive method for the assessment of airway inflammation.

Since the first description of a standardised method [1] there has been an impressive increase of papers in which researchers have used induced sputum to study various aspects of airway inflammation. In order to harmonise the different techniques used worldwide a standardised methodology of sputum induction and processing was issued in 2002 by a European Respiratory Society Task Force [2].

Several studies have shown that evaluation of induced sputum cells is a reproducible and valid technique [3-5]. In particular, one study evaluated the reproducibility of cell counts on cytospins and fluid phase measurements in selected portion of induced sputum. A high reproducibility within sample, between sample and between examiners for all types of cells was reported [3]. Moreover, measurements between different airway diseases were successfully detected, thus confirming the validity of the technique [3].

Reference values and the distribution of cell counts in induced sputum have been provided in a large number of healthy volunteers $[6,7]$. The in- duced sputum was found rich in macrophages and neutrophils and poor in eosinophils, lymphocytes and epithelial cells. These parameters can be used in comparisons with induced sputum cell counts of subjects with airway inflammation [6].

Furthermore, sputum induction has been found to be a simple, safe and well tolerated procedure even in patients with severe lung disease and having exacerbations. However, it has been recommended that experienced personnel carry out the operation and that they apply standard operating procedures, to be aware of the degree of airway obstruction, to use a modified protocol for subjects with severe airway obstruction and to assess lung function and symptoms during sputum induction procedure [8].

Over the last 15 years sputum analysis has become one of the most referenced methods to assess airway inflammation in research and clinical practice [9]. In particular, it has been useful in the characterisation of the type and the extent of airway inflammation in asthma, Chronic Obstructive Pulmonary Disease (COPD) and chronic cough, and has provided much useful knowledge of their inflammatory processes [9].

Although the induced sputum technique has been broadly used in asthma and COPD it may be helpful in the diagnosis of other lung diseases such 


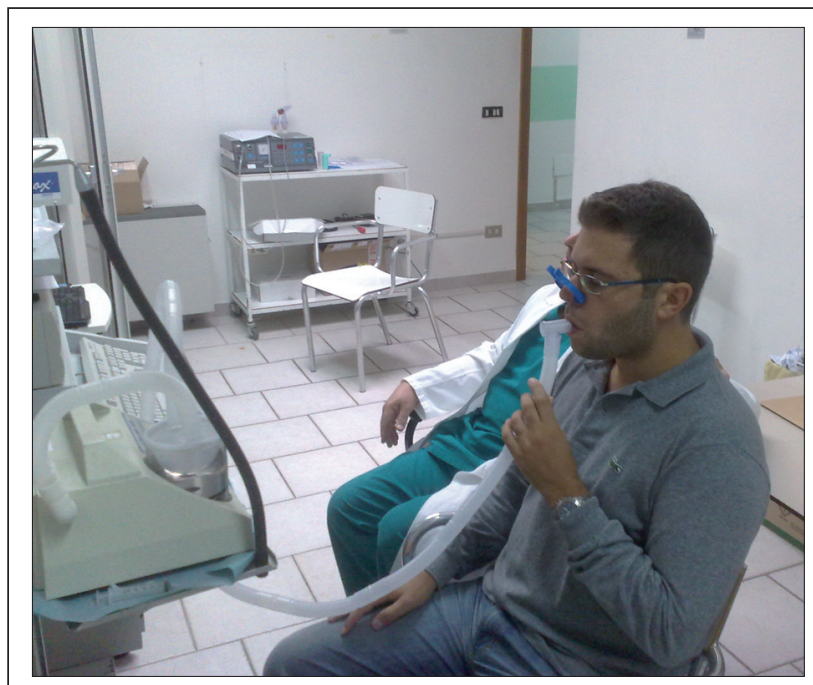

Fig. 1. - Sputum induction.

as lung cancer, cystic fibrosis and interstitial lung diseases.

The aim of the present paper was to review the principal literature on the different markers of inflammation in pulmonary diseases assessed by induced sputum analysis in both cellular and fluid phase.

\section{Asthma}

Since the first study in 1992 [1] many authors have validated the measurements of both cellular and soluble components related to asthma.

These studies have significant in the comprehension of the inflammatory processes that play a role in the development and maintenance of the disease.

Therefore there has recently been a growing interest in the application of induced sputum for monitoring and optimisation of asthma control.

\section{Cellular composition}

Sputum eosinophilia is a typical feature of asthma. Sputum eosinophil count is a validated biomarker for the assessment of airway inflammation that can be easily performed even in clinical setting. Asthmatic patients with sputum eosinophilia have a positive response to corticosteroids, even in ex-smokers and current smokers [10].

Increased sputum eosinophils are associated to a thickening of the greater basement membrane [11]. Some authors have recently suggested that sputum eosinophilia may reflect inadequate control airway inflammation, resulting in an increased risk of exacerbation [12-14].

Conversely, a considerable percentage of corticosteroid-free asthmatics (ranging from 25 to $55 \%$ ) show a neutrophilic inflammation [15-17]. This condition is called non-eosinophilic asthma and it is important to identify because it is associated with a poor response to corticosteroids [16].

\section{Fluid-phase mediators}

Although the validity and reproducibility of several techniques has not been assessed yet, many potential biomarkers can be examined in induced sputum supernatant (table 1).

Table 1. - Markers of airway inflammation in cellular and fluid phase in each pulmonary disease. For abbreviations legend see text

\begin{tabular}{|c|c|c|c|c|}
\hline & Asthma & COPD & Cystic fibrosis & Sarcoidosis \\
\hline CELLULAR PHASE & $\begin{array}{l}\uparrow \text { Eosinophils } \\
\uparrow \text { Neutrophils (non-eosinophilic asthma) }\end{array}$ & $\begin{array}{l}\uparrow \text { Neutrophils } \\
\uparrow \text { Eosinophils (likely overlap with asthma. } \\
\text { Better response to corticosteroids) } \\
\uparrow \mathrm{CD} 8+\mathrm{T} \text {-lymphocytes }\end{array}$ & $\begin{array}{l}\uparrow \text { Total cell count } \\
\uparrow \text { Neutrophils }\end{array}$ & $\uparrow$ Lymphocytes \\
\hline FLUID PHASE & $\begin{array}{l}\uparrow \mathrm{ECP} \\
\uparrow \mathrm{MPO} \\
\uparrow \text { Albumin } \\
\uparrow \text { Fibrinogen } \\
\uparrow \text { Nonkinase plasminogen activator } \\
\uparrow \text { Plasminogen activator inhibitor } \\
\uparrow \text { Neurokinin A } \\
\uparrow \text { IL-8 } \\
\uparrow \text { IL-13 } \\
\uparrow \mathrm{CYS}-\mathrm{LTS} \\
\uparrow 8 \text {-Isoprostane } \\
\uparrow \mathrm{MMP}-9 / \mathrm{TIMP} \text { ratio }\end{array}$ & $\begin{array}{l}\uparrow \mathrm{IL}-8 \\
\uparrow \mathrm{IL}-6 \\
\uparrow \mathrm{TNF}-\alpha \\
\downarrow \mathrm{IL}-10 \\
\uparrow \text { Leptin } \\
\uparrow \mathrm{MPO} \\
\uparrow \mathrm{HNL} \\
\uparrow \mathrm{NE} \\
\uparrow \mathrm{ECP} \\
\uparrow \mathrm{EPO} \\
\uparrow \mathrm{LTB}-4 \\
\uparrow \text { GRO-a } \\
\uparrow \mathrm{MCP}-1 \\
\uparrow \text { GM-CSF } \\
\uparrow \text { MMP-1, -8, -9,-12 } \\
\uparrow \text { Hyaluronan }\end{array}$ & $\begin{array}{l}\uparrow \mathrm{IL}-8 \\
\uparrow \mathrm{NE}\end{array}$ & \\
\hline
\end{tabular}


Eosinophil Cationic Protein (ECP) and Myeloperoxidase (MPO) are granulocyte proteins that are well correlated with eosinophil cell count [18] and decrease after anti-nflammatory treatment $[19,20]$.

Levels of leakage markers such as albumin and fibrinogen were found increased in subjects with asthma compared to healthy subjects [4] and their concentrations are related to asthma severity [21, 22].

Moreover, recent studies showed that asthmatic subjects have increased concentrations of nonkinase plasminogen activator and plasminogen activator inhibitor [23] compared to controls and Neurokinin A significantly raises during exacerbations [24]. Interleukin-8 (IL-8) is a neutrophil chemoattractant which has been shown to be increased during asthma exacerbations [25] and in patients with severe persistent asthma [17], suggesting a role for monitoring asthma exacerbations and assessing the effectiveness of a medication in severe asthmatics. IL-13 is another cytokine whose levels were found higher in asthmatics than controls [26]. However it occurred in less than $50 \%$ of asthmatics and no correlation with asthma severity was found [26].

Cysteinyl leukotrienes (Cys-LTs) and 8-isoprostane are inflammatory mediators involved in the pathophysiology of asthma $[27,28]$. Both have been extensively studied during recent years [29, 30 ] and their concentration correlates with severity of disease and are relatively unaffected by corticosteroids [31-33]. However 8-isoprostane was not found to be increased in newly diagnosed subjects with asthma [34]. Finally, asthmatic subjects show a higher level of Matrix metalloproteinasis-9 (MMP-9) [35-39]. In the process of remodelling an impairment in the balance between MMP-9 and its counterpart tissue inhibitor of metalloproteinases (TIMP) occurs. Indeed, asthmatic subjects have an increase in MMP-9/TIMP ratio that is related to the disease severity $[35,36,40]$.

\section{Chronic obstructive pulmonary disease}

Induced sputum has been broadly used to investigate the inflammatory mechanism of COPD and it has provided considerable information about the inflammatory process of this disease. Although patients with COPD expectorate spontaneously it is suggested to perform induced sputum, since spontaneous sputum may contain a high amount of dead cells [4] that may lead to errors during cell count and fluid-phase mediators measurements [41, 42].

\section{Cellular composition}

An increase in the percentage of neutrophils is the typical feature in subjects with COPD [43-45]. Neutrophils are increased compared to asymptomatic smokers and there is a negative correlation between neutrophil counts and $\mathrm{FEV}_{1}$ [46]. This indicates that neutrophils are relevant in the pathogenesis of COPD.

Some COPD patients show an increased number of eosinophils, indicating a likely overlap with asthma, and this seems to predict a better response to bronchodilators and inhaled corticosteroids [47].

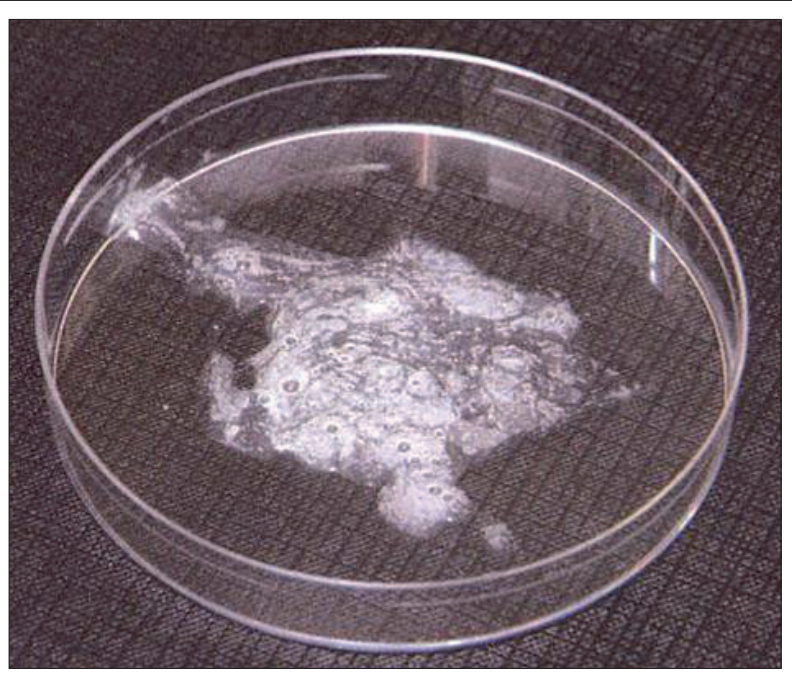

Fig. 2. - Sample of induced sputum.

Moreover, CD8+ T-cells are increased in induced sputum of patients with COPD [48]. It has been shown that the CD8+ T-cells involved in COPD are type 1 [49]. Type 1 cells play a role in the response to viral infections that are frequent in patients with COPD [50].

\section{Inflammatory mediators}

Many inflammatory mediators have been analysed in the fluid-phase of induced sputum (table 1). Several cytokines, chemokines, eicosanoids, markers of oxidative stress show an increase in COPD compared to asymptomatic smokers, with a further increase during exacerbations. In particular, inflammatory cytokines, including Interleukin-8 (IL-8), Interleukin 6 (IL-6) and Tumour Necrosis Factor-alpha (TNF- $\alpha$ ) have been extensively studied and reported increased in sputum of COPD patients compared to normal smokers [51-54] and their concentrations are related to the severity of the disease [55]. However the inflammatory cytokine Interleukin-10 (IL-10) are reduced in sputum of healthy smokers and, to a greater extent, in smokers with COPD [56], suggesting a role of the imbalance between cytokines with different properties in the smoke-induced lung damage.

Induced sputum of patients with COPD shows an increase of Leptin that is correlated with other inflammatory markers including TNF- $\alpha$ and C-reactive protein (CRP) [57].

Moreover, sputum fluid-phase in COPD shows an increase in neutrophilic and eosinophilic granulocyte proteins such as Myeloperoxidase (MPO), Human Neutrophil Lipocalin (HNL), Neutrophil Elastase (NE) and Eosinophilic Cationic Protein (ECP), Eosinophil Peoxidase (EPO) and chemoattractants like Leukotriene B-4 (LTB-4), Growth Related Oncogen-a (GRO-a), Monocyte Chemotactic Protein-1 (MCP-1) and Granulocyte Macrophages-Colony Stimulating Factor (GMCSF) [58-60].

Increased sputum concentration of proteins, including neutrophil Elastase and Metallopro- 


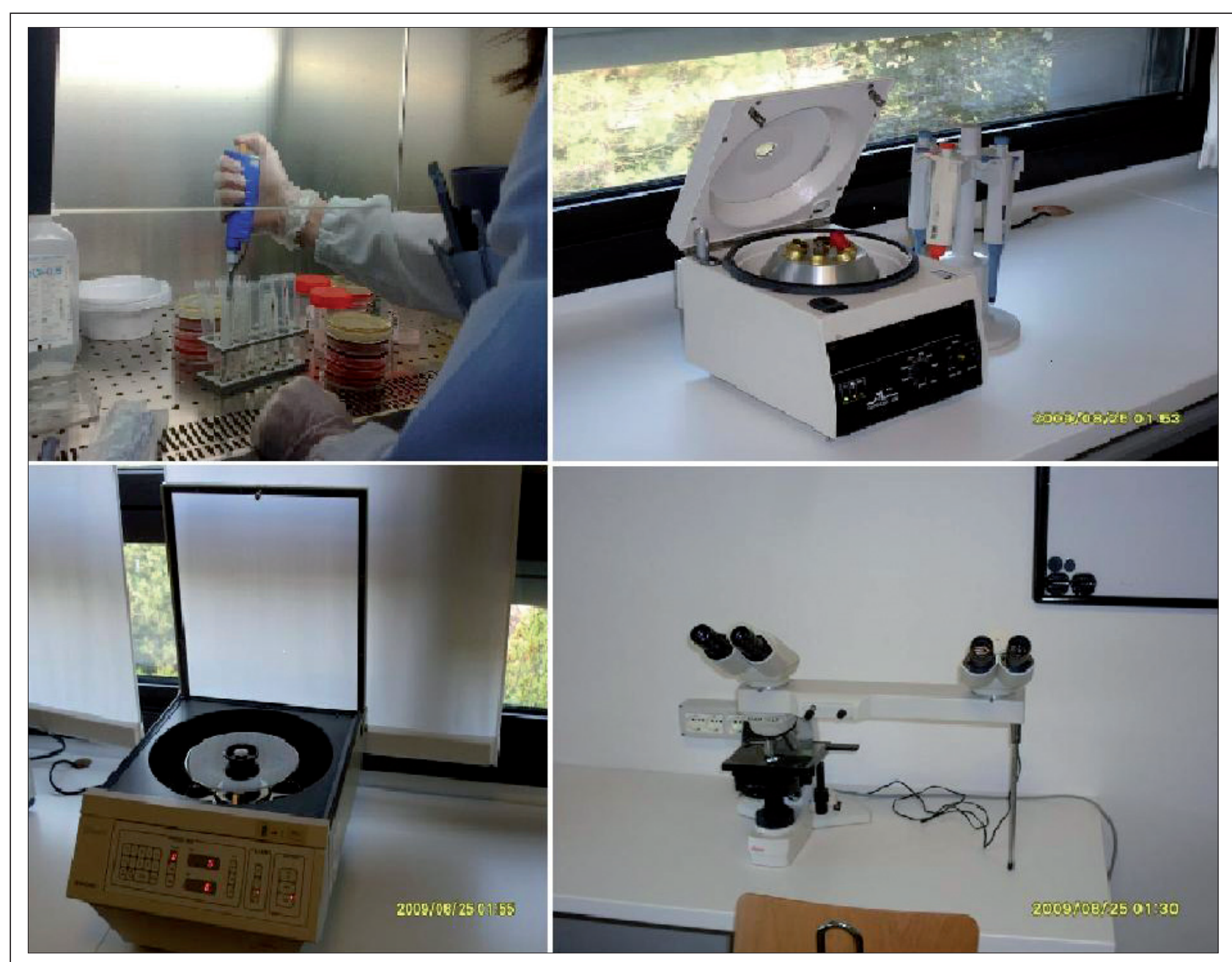

Fig. 3. - Sputum processing. Proper facilities and well-trained personnel are required.

teinases 1,8,9 and 12 (MMP-1, -8, -9 and 12) as well as decreased Antiproteasis (TIMP-1) strongly support the oxidant-antioxidant and proteinase-antiproteinase imbalance hypothesis for the pathogenesis of COPD [59, 61-63].

Finally, higher levels of Hyaluronan indicate a leakage in the extracellular matrix in COPD [64].

\section{Cystic fibrosis}

Cystic fibrosis is the most common lethal genetically inherited disease characterised by a self perpetuating cycle of airway obstruction, chronic bacterial infection, and vigorous inflammation that results in bronchiectasis, progressive obstructive lung disease, and marked shortening of life expectancy [65]. Airway inflammation plays an important role in the progression of cystic fibrosis. Thus, inflammatory biomarkers in sputum of patients with cystic fibrosis can be utilised for monitoring disease progression and evaluation of treatment.

Airway inflammation in cystic fibrosis is characterised by the presence of abundant amounts of neutrophils, neutrophil products, as well as epithelial cells, macrofages, T lymphocytes, B lymphocytes, dendritic cells and mast cells [66]. Sputum has been used extensively to evaluate airway inflammation in cystic fibrosis. Various markers in- cluding inflammatory cells, cytokines, cytokine antagonists, neutrophil chemoattractants, proteases, antiproteases, markers of oxidative stress, antioxidants, plasma exudates markers, antimicrobial proteins, antimicrobial peptides, nitric oxide metabolites and pathway, eicosanoids, mucins, adhesion molecules, markers of structural airway injury and components of signaling cascades that can be measured in sputum were suggested [66].

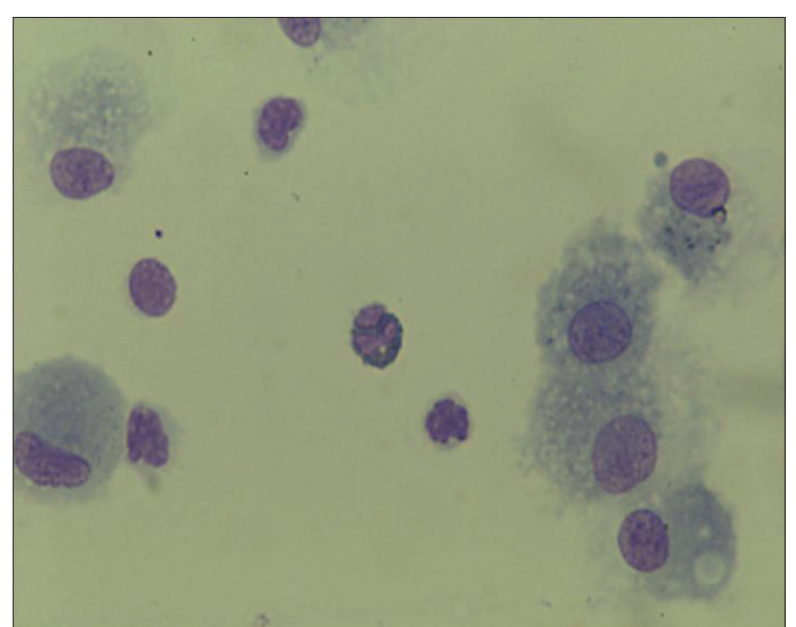

Fig. 4. - Cytospin of a normal subject. A higher percentage of Macrophages is the typical feature. Magnification 40X. 
The most important indicators of airway inflammation in sputum of patients with cystic fibrosis are the increase of total cell counts, as well as neutrophil counts and increased level of interleukin-8 [67]. Inflammatory markers can be studied in spontaneously produced and induced sputum. Administration of sputum induction is a good solution to evaluate airway inflammation in patients who are not able to produce sputum spontaneously. Total cell counts, as well as neutrophil counts in induced sputum are significantly increased in comparison with sputum obtained from healthy individuals [68]. However, the degree of this inflammation is not significantly different from those evaluated in patients with cystic fibrosis who have a productive cough and can produce sputum spontaneously [68]. Similarly, IL-8 levels and neutrophil elastase activity are similar in spontaneously produced and induced sputum [68]. This indicates that the analysis of induced and/or spontaneously produced sputum can provide relevant useful information for evaluation and monitoring of patients with cystic fibrosis. However, other studies are required to further investigate relationship between variability of inflammatory biomarkers and disease severity.

\section{Lung cancer}

Lung cancer has an important clinical and socio-economical significance, as it is the most common and the most lethal cancer in many countries of the world. Several studies have documented the possibility of diagnosing lung cancer by using sputum cytology [69-71]. A method based on identification of biomarkers of lung cancer in the sputum of suspects can be performed for early diagnosis of this pathology. This can be very useful especially in patients affected by early stage of lung cancer when traditional methods of diagnosis are not yet able to reveal the disease. For example, sputum cytology is useful in finding early central lung cancer, particularly squamous cell carcinoma in situ and microinvasive squamous cell carcinoma [70]. However, most of the studies demonstrated that sputum cytology had low sensitivity in discovering clinical lung cancer [71]. The poor sensitivity of sputum cytology can be explained by an inadequate sample of sputum collected for cytological examination. Induction of sputum in subjects who are not able to produce sputum spontaneously or who produce inadequate samples of sputum may solve the problem. In addition, sputum induction may presumably provide more robust samples and increase sensitivity of cytological examination in subjects who produce samples of sputum suitable for analysis. Advances in improved yield of expectoration and improved methods of evaluating sputum are crucial points for future investigations.

\section{Sarcoidosis}

Sarcoidosis is a systemic granulomatous disease characterised by a T-helper-1 response with accumulation of CD4+ lymphocytes and activated

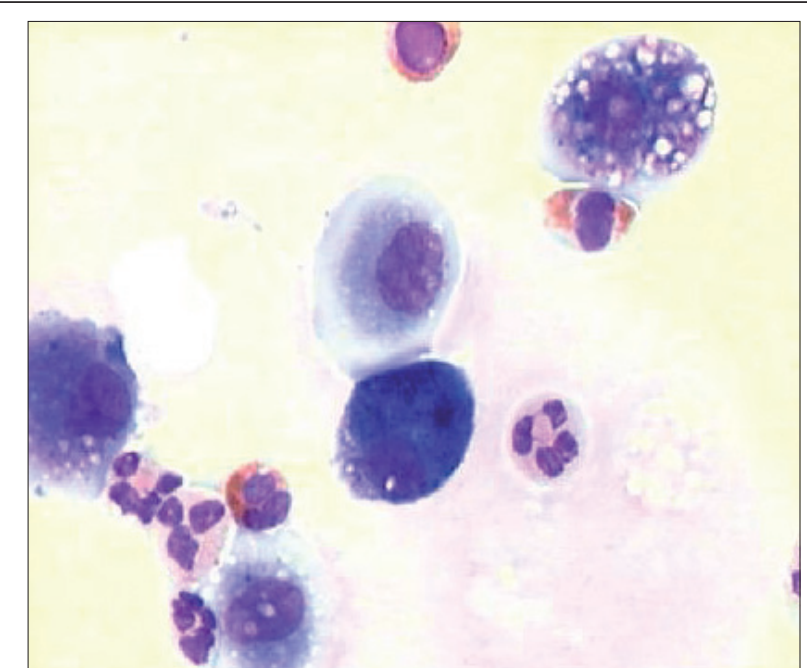

Fig. 5. - Cytospin of a patient with COPD. Neutrophils are prevailing. Magnification 100X.

macrophages in the lungs and affected organs, resulting in granuloma formation [72]. The immune response in the pathogenesis of sarcoidosis is mediated by alveolar macrophages and lymphocytes making these two cells biomarkers of the disease. Some studies have demonstrated that sputum of a patients with sarcoidosis is characterised by relatively high lymphocyte counts [73]. However, the evidence of other biomarkers is missing. Identification of mediators secreted by lymphocyte in sputum of patients with sarcoidosis is the objective for future research.

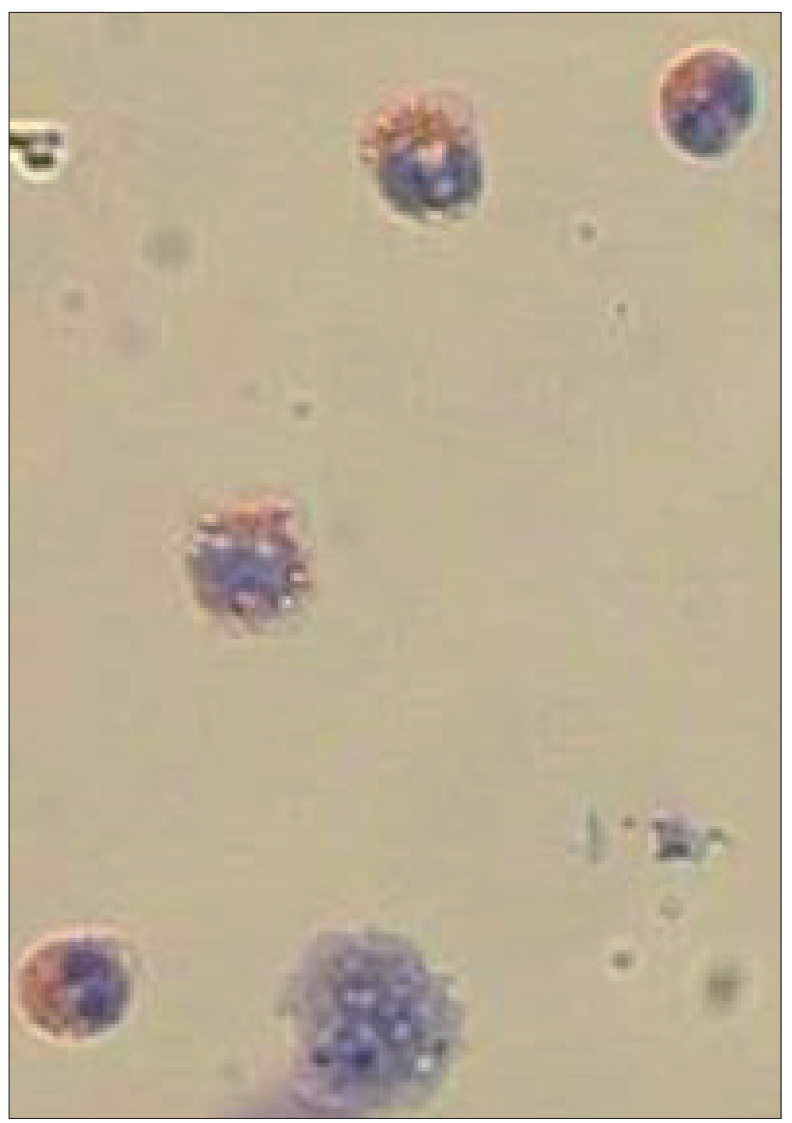

Fig. 6. - Cytospin of a patient with asthma. Eosinophils are abundant. Magnification 100X. 


\section{Conclusions}

As seen above induced sputum is a validated technique that can be applied in several pulmonary diseases both for research and diagnosis and it has potentials for a large-scale application in several clinical settings.

It is important to consider the most relevant advantages and disadvantages of the discussed technique. Induced sputum has several pro's including reproducibility of differential cell count on cytospins, the possibility to sample multiple biomarkers, its validity as a tool for assessment of anti-inflammatory therapy and its relative non-invasiveness.

However a number of cons have to be taken into account. Sputum induction and processing are expensive and time-consuming procedures that require well-equipped laboratories with trained personnel and rescue medication promptly available.

Moreover, adequate samples cannot be obtained from all the subjects ( $80 \%$ on average) and sputum induction should not be performed in patients with severe persistent bronchocostiction and/or co-morbidities such as cardiovascular disorders.

Induced sputum should not be repeated over a short-term period $(<48 / \mathrm{h})$ as it may affect the composition of inflammatory cells and mediators in the airways $[74,75]$.

Finally, the processing of sputum with dithiotreitol may affect the measurement of fluidphase mediators for its action on disulphide bonds [76-78] and the lack of a validated dilution factor may lead to incomparable measurements among authors.

\section{References}

1. Pin I, Gibson PG, Kolendovicz, et al. Use of induced sputum cell counts to investigate airway inflammation in asthma. Thorax 1992; 47: 25-9.

2. Djukanovic R, Sterk PJ, Fahy JV, et al. Standardised methodology of sputum induction and processing. Eur Respir J 2002; 20: Suppl 37.

3. Spanevello A, Migliori GB, Sharara A, et al. Induced sputum to assess airway inflammation: a study of reproducibility. Clin Exp Allergy 1997; 27: 1138-44.

4. Pizzichini E, Pizzichini MMM, Efthimiadis A, et al. Indices of airway inflammation in induced sputum: reproducibility and validity of cell fluid phase measurements. Am J Respir Crit Care Med 1996; 154: 308-317.

5. Spanevello A, Beghè B, Bianchi A, et al. Comparison of two methods of processing induced sputum: selected versus entire sputum. Am J Respir Crit Care Med 1998; 157: 665-668.

6. Spanevello A, Confalonieri M, Sulotto F, et al. Induced sputum cellularity. Reference values and distribution in normal volunteers. Am J Respir Crit Care Med 2000; 62 (3 Pt 1): 1172-4.

7. Balbi B, Pignatti P, Corradi M, et al. Bronchoalveolar lavage, sputum and exhaled clinically relevant inflammatory markers: values in healthy adults. Eur Respir $J$ 2007; 30: 769-81.

8. Pizzichini E, Pizzichini MMM, Leigh R, et al. Safety of sputum induction. Eur Respir J 2002; 20: suppl 37, $9 \mathrm{~s}-18 \mathrm{~s}$.
9. Brightling CE. Clinical applications of induced sputum. Chest 2006; 129; 1344-1348.

10. Bacci E, Cianchetti S, Bartoli M, et al. Low sputum eosinophils predict the lack of response to beclomethasone in symptomatic asthmatic patients. Chest 2006; 129: 565-72.

11. Haldar P, Pavord ID, Shaw DE. Cluster analysis and clinical asthma phenotypes. Am J Respir Crit Care Med 2008; 178: 218-224.

12. Green RH, Brightling CE, McKenna S. Asthma exacerbations and sputum eosinophil counts: a randomised controlled trial. Lancet 2002; 360: 1715-1721.

13. Jayaram L, Pizzichini MM, Cook RJ. Determining asthma treatment by monitoring sputum cell counts: effect on exacerbations. Eur Respir J 2006; 27: 483-494.

14. Leckie MJ, Ten Brinke A, Khan J. Predictors for failed dose reduction of inhaled corticosteroids in childhood asthma. Respirology 2008; 13: 400-407.

15. Green RH, Brightling CE, Woltmann G. Analysis of induced sputum in adults with asthma: identification of subgroup with isolated sputum neutrophilia and poor response to inhaled corticosteroids. Thorax 2002; 57: 875-879.

16. Pavord ID, Brightling CE, Woltmann G. Non-eosinophilic corticosteroid unresponsive asthma. Lancet 1999; 353: 2213-2214.

17. Gibson PG, Simpson JL, Saltos N. Heterogeneity of airway inflammation in persistent asthma: evidence of neutrophilic inflammation and increased sputum interleukin-8. Chest 2001; 119: 1329-1336.

18. Efthimiadis MM, Pizzichini E, Pizzichini J, Dolovich FE. Hargreave, Induced sputum cell and fluid-phase indices of inflammation: comparison of treatment with dithiothreitol vs phosphate-buffered saline. Eur Respir $J$ 1997; 10: 1336-1340.

19. Bacci E, Di Franco A, Batoli ML, Carnevali S, Cianchetti S, Dente FL. Comparison of anti-inflammatory and clinical effects of beclomethasone dipropionate and salmeterol in moderate asthma, Eur Respir J 2002; 20: 66-72.

20. Perng DW, Huang HY, Lee YC, Perng RP. Leukotriene modifier vs inhaled corticosteroid in mild-to-moderate asthma: clinical and anti-inflammatory effects. Chest 2004; 125: 1693-1699.

21. Louis R, Lau L, Bron A, Roldaan A, Radermecker M, Djukanovic R, The relationship between airways inflammation and asthma severity. Am J Respir Crit Care Med 2000; 161: 9-16.

22. In 'T Veen JC, De Gouw HW, Smits HH, Sont JK, Hiemstra PS, Sterk PJ. Repeatability of cellular and soluble markers of inflammation in induced sputum from patients with asthma, Eur Respir J 1996; 9: 2441-2447.

23. Kowal K, Zukowski S, Moniuszko M, BodzentaLukaszyk A. Plasminogen activator inhibitor-1 (PAI-1) and urokinase plasminogen activator (uPA) in sputum of allergic asthma patients. Folia Histochem Cytobiol 2008; 46: 193-198.

24. Mostafa GA, Reda SM, Abd El-Aziz MM, Ahmed SA. Sputum neurokinin A in Egyptian asthmatic children and adolescents: relation to exacerbation severity. $\mathrm{Al}$ lergy 2008; 63: 1244-1247.

25. Norzila MZ, Fakes K, Henry R, Simpson J, Gibson PG. Interleukin-8 secretion and neutrophil recruitment accompanies induced sputum eosinophil activation in children with acute asthma. Am J Respir Crit Care Med 2000; 161: 769-774.

26. Saha SK, Berry MA, Parker D. Increased sputum and bronchial biopsy IL-13 expression in severe asthma. $J$ Allergy Clin Immunol 2008; 121: 685-691.

27. Diamant, Sampson AP. Anti-inflammatory mechanisms of leukotriene modulators. Clin Exp Allergy 1999; 29: 1449-1453. 
28. Dworski R. Oxidant stress in asthma. Thorax 2000; 55: 51S-55S.

29. Macfarlane A, Dworski R, Sheller J, Pavord ID, Barry Kay A, Barnes PJ. Sputum cysteinyl leukotrienes increase $24 \mathrm{~h}$ after allergen inhalation in atopic asthmatics. Am J Respir Crit Care Med 2000; 160: 1553-1558.

30. Pavord ID, Ward R, Woltmann G, Wardlaw AJ, Sheller J, Dworski R. Induced sputum eicosanoid concentrations in asthma. Am J Respir Crit Care Med 1999; 160: 1905-1909.

31. Wood L, Garg M, Simpson JL, Mori T, Croft K, Wark P. Induced sputum 8-isoprostane concentrations in inflammatory airway diseases. Am J Respir Crit Care Med 2005; 171: 426-430.

32. Mondino C, Ciabattoni G, Koch P, Pistelli R, Trove A, Barnes PJ. Effects of inhaled corticosteroids on exhaled leukotrienes and prostanoids in asthmatic children. $J$ Allergy Clin Immunol 2004; 114: 761-767.

33. Lex DN, Payne A, Zacharasiewicz AM, Li NM, Wilson TT Hansel. Sputum induction in children with difficult asthma: safety, feasibility, and inflammatory cell pattern. Pediatr Pulmonol 2005; 39: 318-324.

34. Louhelainen N, Rytilä P, Obase Y. The value of sputum 8 -isoprostane in detecting oxidative stress in mild asthma. J Asthma 2008; 45: 149-154.

35. Boulay ME, Prince P, Deschesnes F, Chakir J, Boulet LP. Metalloproteinase-9 in induced sputum correlates with the severity of the late allergen-induced asthmatic response. Respiration 2004; 71: 216-224.

36. Cataldo DD, Bettiol J, Noel A, Bartsch P, Foidart JM, Louis R. Matrix metalloproteinase-9, but not tissue inhibitor of matrix metalloproteinase-1, increases in the sputum from allergic asthmatic patients after allergen challenge. Chest 2002; 122: 1553-1559.

37. Hoshino M, Nakamura Y, Sim J, Shimojo J, Isogai S. Bronchial subepithelial fibrosis and expression of matrix metalloproteinase-9 in asthmatic airway inflammation. J Allergy Clin Immunol 1998; 102: 783-788.

38. Ko F, Diba C, Roth M, McKay K, Johnson P, Salome C. A comparison of airway and serum matrix metalloproteinase- 9 activity among normal subjects, asthmatic patients, and patients with asthmatic mucus hypersecretion. Chest 2005; 127: 1919-1927.

39. Mattos W, Lim S, Russell R, Jatakanon A, Chung KF, Barnes PJ. Matrix metalloproteinase-9 expression in asthma: effect of asthma severity, allergen challenge, and inhaled corticosteroids. Chest 2002; 122: 15431552.

40. Vignola AM, Riccobono L, Mirabella A, Profita M, Chanez P, Bellia V. Sputum metalloproteinase-9/tissue inhibitor of metalloproteinase-1 ratio correlates with airflow obstruction in asthma and chronic bronchitis. Am J Respir Crit Care Med 1998; 158: 1945-1950.

41. Tsoumakidou M, Tzanakis N, Siafakas NM. Induced sputum in the investigation of airway inflammation of COPD. Respir Med 2003; 97: 863-871.

42. Bhowmik A, Seemungal TA, Sapsford RJ, Devalia JL, Wedzicha JA. Comparison of spontaneous and induced sputum for investigation of airway inflammation in chronic obstructive pulmonary disease. Thorax 1998; 53: 953-956.

43. Jeffery PK. Structural and inflammatory changes in COPD: a comparison with asthma. Thorax 1998; 53: 129-36.

44. Saetta M. Airway inflammation in chronic obstructive pulmonary disease. Am J Respir Crit Care Med 1999; 160: S17-20.

45. Cosio Piqueras MG, Cosio MG. Disease of the airways in chronic obstructive pulmonary disease. Eur Respir J Suppl 2001; 34: 41s-49s

46. Stănescu D, Sanna A, Veriter, et al. Airways obstruction, chronic expectoration, and rapid decline of $\mathrm{FEV}_{1}$ in smokers are associated with increased levels of sputum neutrophils. Thorax 1996; 51: 267-71.

47. Papi A, Romagnoli M, Baraldo S, et al. Partial reversibility of airflow limitation and increased exhaled $\mathrm{NO}$ and sputum eosinophilia in chronic obstructive pulmonary disease. Am J Respir Crit Care Med 2000; 162: 1773-1777.

48. Tzanakis N, Chrysofakis G, Tsoumakidou M, et al. Induced sputum $\mathrm{CD}^{+} \mathrm{T}$-lymphocyte subpopulations in chronic obstructive pulmonary disease. Respir Med 2004; 98: 57-65.

49. Saetta M, Mariani M, Panina-Bordignon $\mathrm{P}$, et al. Increased expression of the chemokine receptor CXCR3 and its ligand CXCL10 in peripheral airways of smokers with chronic obstructive pulmonary disease. $A m J$ Respir Crit Care Med 2002; 165: 1404-9.

50. Fabbri L, Beghé B, Caramori G, Papi A, Saetta M. Similarities and discrepancies between exacerbations of asthma and chronic obstructive pulmonary disease. Thorax 1998; 53: 803-8.

51. Keatings VM, Collins PD, Scott DM, Barnes PJ. Differences in interleukin-8 and tumor necrosis factor-alpha in induced sputum from patients with chronic obstructive pulmonary disease or asthma. Am J Respir Crit Care Med 1996; 153: 530-534.

52. Yamamoto C, Yoneda T, Yoshikawa M, Fu A, Tokuyama T, Tsukaguchi K, Narita N. Airway inflammation in COPD assessed by sputum levels of interleukin-8. Chest 1997; 112: 505-510.

53. Aaron SD, Angel JB, Lunau M, Wright K, Fex C, Le Saux N, Dales RE. Granulocyte inflammatory markers and airway infection during acute exacerbation of chronic obstructive pulmonary disease. Am J Respir Crit Care Med 2001; 163: 349-355.

54. Vernooy JH, Kucukaycan M, Jacobs JA, et al. Local and systemic inflammation in patients with chronic obstructive pulmonary disease: soluble tumor necrosis factor receptors are increased in sputum. Am J Respir Crit Care Med 2002; 166: 1218-1224.

55. Hacievliyagil SS, Gunen H, Mutlu LC, Karabulut AB, Temel I. Association between cytokines in induced sputum and severity of chronic obstructive pulmonary disease. Respir Med 2006; 100: 846-854.

56. Takanashi S, Hasegawa Y, Kanehira Y, et al. Interleukin-10 level in sputum is reduced in bronchial asthma, COPD and in smokers. Eur Respir J 1999; 14: 309-14.

57. Broekhuizen R, Vernooy JH, Schols AM, Dentener MA, Wouters EF. Leptin as local inflammatory marker in COPD. Respir Med 2005; 99: 70-74.

58. Keatings VM, Barnes PJ. Granulocyte activation markers in induced sputum: comparison between chronic obstructive pulmonary disease, asthma, and normal subjects. Am J Respir Crit Care Med 1997; 155: 449-53.

59. Hill AT, Bayley D, Stockley RA. The interrelationship of sputum inflammatory markers in patients with chronic bronchitis. Am J Respir Crit Care Med 1999; 160: 893-898.

60. Traves SL, Culpitt SV, Russell RE, Barnes PJ, Donnelly LE. Increased levels of the chemokines GROalpha and MCP-1 in sputum samples from patients with COPD. Thorax 2002; 57: 590-5.

61. Kanazawa H, Shiraishi S, Hirata K, Yoshikawa J. Imbalance between levels of nitrogen oxides and peroxynitrite inhibitory activity in chronic obstructive pulmonary disease. Thorax 2003; 58: 106-9.

62. Cataldo D, Munaut C, Noël A, et al. MMP-2- and MMP-9-linked gelatinolytic activity in the sputum from patients with asthma and chronic obstructive pulmonary disease. Int Arch Allergy Immunol 2000; 123: 259-67.

63. Beeh KM, Beier J, Kornmann O, Buhl R. Sputum matrix metalloproteinase-9, tissue inhibitor of metalloprotinease-1, and their molar ratio in patients with 
chronic obstructive pulmonary disease, idiopathic pulmonary fibrosis and healthy subjects. Respir Med 2003; 97: 634-9.

64. Dentener MA, Vernooy JH, Hendriks S, Wouters EF. Enhanced levels of hyaluronan in lungs of patients with COPD: relationship with lung function and local inflammation. Thorax 2005; 60: 114-119.

65. Davis PB, Drumm M, Konstan MW. Cystic fibrosis. Am J Respir Crit Care Med 1996; 154: 1229-1256.

66. Sagel SD, Chmiel JF, Konstan MW. Sputum biomarkers of inflammation in cystic fibrosis lung disease. Proc Am Thorac Soc 2007; 4: 406-417.

67. Sagel SD, Sontag MK, Wagener JS, Kapsner RK, Osberg I, Accurso FJ. Induced sputum inflammatory measures correlate with lung function in children with cystic fibrosis. J Pediatr 2002; 141: 811-817.

68. Sagel SD, Kapsner R, Accurso FJ. Airway ingflammation in children with cystic fibrosis and healthy children assessed by sputum induction. Am J Respir Crit Care Med 2001; 164: 1425-1431.

69. Kaneko M, Eguchi K, Ohmatsu H, et al. Periferal lung cancer: screening and detection with low dose spiral CT versus radiography. Radiology 1996; 201: 798-802.

70. Cortese DA, Pairolero PC, Bergstralh EJ, et al. Roentgenographically occult lung cancer. A ten-year experience. J Thorac Cardiovasc Surg 1983; 86: 373380 .
71. Kennedy TC, Hirsch FR. Using molecular markers in sputum for the early detection of lung cancer: a review. Lung Cancer 2004; 45 S2: S21-S27.

72. Bargagli E, Mazzi A, Rottoli PR. Markers of inflammation in sarcoidosis: blood, urine, BAL, sputum and exhaled gas. Clin Chest Med 2008; 29: 445-458.

73. Fireman E, Costabel U eds. Induced sputum in interstitial and occupational lung diseases. An Atlas of Induced Sputum. Partheon Publishing 2004; pp. 121-127.

74. Holz O, Richer K, Jorres RA, Speckin P, Mucke M, Magnussen $\mathrm{H}$. Changes in sputum composition between two induction performed on consecutive days. Thorax 1998; 53: 83-86.

75. Nightingale JA, Rogers DF, Barnes PJ. Effect of repeated sputum induction on cell counts in normal volunteers. Thorax 1998; 53: 87-90.

76. Stockley RA, Bayley DL. Validation of assays for inflammatory mediators in sputum. Eur Respir J 2000; 15: 778-781.

77. Hamid Q, Kelly MM, Linden M, Louis R. Methods of sputum processing for cell counts, immunocytochemistry and in situ hybridisation. Eur Respir J 2002; 20: 19S-23S.

78. Pignatti P, Delmastro M, Perfetti L, et al. Is dithiothreitol affecting cells and soluble mediators during sputum processing? A modified methodology to process sputum. J Allergy Clin Immunol 2002; 110: 667-8.

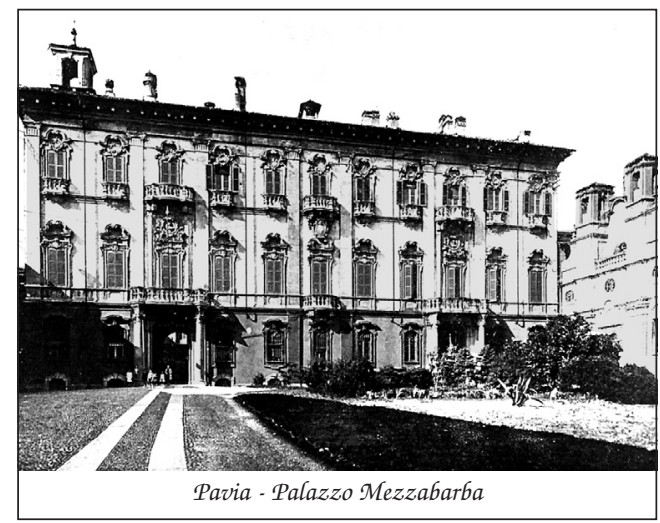

